\title{
IF HIGHER EDUCATION IS A RIGHT, AND DISTANCE EDUCATION IS THE ANSWER, THEN WHO WILL PAY?
}

\author{
Dr. Katrina A. Meyer \\ Associate Professor of Higher and Adult Education \\ The University of Memphis
}

\begin{abstract}
If higher education is a right, and distance education is the avenue for making higher education universally available, then who shall pay? This article asks (1) can state governments in the United States afford to fund this initiative and (2) can public higher education institutions in the U.S. fund this effort through capitalizing on cost-efficiencies of online learning? To answer the first question, data on funding of higher education by states are reviewed and a negative conclusion reached. To answer the second question, research on methods for achieving cost-efficiencies through online learning is reviewed and a cautious positive conclusion is reached, assuming states and institutions are willing to invest in the people and processes, and the time, effort, and will that make achieving efficiencies possible.
\end{abstract}

\section{KEYWORDS}

Enrollment Growth, Funding, Cost-Efficiencies, U.S. Public Higher Education

\section{INTRODUCTION}

Rather than discuss the fundamental issues posed by the question, "What is the role of distance education in the implementation of the right to education?" this paper will assume that (a) higher education is a right and (b) distance education has been deemed one of the possible solutions to providing higher education to all individuals desiring an education. However, there is a more practical issue that requires attention: how shall such an initiative be funded? In other words, who shall pay for the "right to education," in this case, higher education? Therefore, the questions that this paper will attempt to answer are: (1) can state governments in the United States afford to fund this initiative and (2) can public higher education institutions in the U.S. fund this initiative through capitalizing on cost-efficiencies of online learning?

The discussion will be limited to conditions in the U.S. This limitation is understandable since it is critical to assess the ability of states and their public U.S. higher education institutions to respond to this initiative. Similar analyses should be undertaken on other types of higher education institutions, including private colleges and universities and higher education institutions in other nations.

\section{LITERATURE}

The last decade began with a declining sense of financial security in U.S. public higher education. For example, 20 states cut funding for higher education in 2001 [1] and 25 states reduced higher education funding in 2003 [2]; even in states that kept funding level or slightly increased it, enrollment often increased. That meant per-student funding level was effectively declining. Projections are more dire: all 50 states are expected to face budget deficits by 2013 [3]. 
In 2002, Breneman [4] concluded that states' problems with sustaining or growing resources was structural and not temporary. States' current financial problems are the result of a number of forces that show little sign of abating. This includes the demand for more funding for K-12 education as a result of student enrollment growth and No Child Left Behind, more funding needed for Medicare, welfare, prisons, and transportation, and the limits of taxpayer willingness to pay increased taxes. Taxpayer revolts range from the passage in 1978 of proposition 13 in California (limiting property taxes), passage of Measure 5 in 1990 in Oregon (which placed a limit on property taxes in the state Constitution), the passage of Initiative 601 in 1993 in Washington (limiting state spending), passage of the Taxpayer Bill of Rights (TABOR) in 1992 in Colorado (a tax limitation measure), and the 1980 passage of proposition 2 1/2 in Massachusetts (also a property tax limitation law). Limiting property taxes has also been a ballot issue during 2005 in Connecticut, Maine, Minnesota, Nevada, New Jersey, Pennsylvania, Tennessee, Texas, and South Carolina [5]. All states now offer limitations on property taxes for older individuals [6]. These movements indicate that state tax structures are part of the problem, since many states depend on property taxes or sales taxes for revenue, which tend to be regressive and generate taxpayer revolts. And a dependence on state income taxes is not welcome, either, since these depend on the economic health of the state's population and wages that keep up with inflation as well as rising costs.

Recent news that revenues flowing into state coffers are improving [7] does not necessarily bode well for higher education. Of the 49 states seeing revenue growth in 2006, only 14 indicated they planned to spend some of this revenue on higher education [8]. Clearly, the competition for these excess resources after a period of declining resources will be fierce. Whether and to what extent the economy recovers and any additional revenues go to higher education waits to be seen. Given the recent crisis caused by failures within the sub-prime mortgage industry and a slowing economy, perhaps there is even less cause for optimism. During the period of poor budgets, higher education faced increased costs, cut programs, delayed maintenance, and otherwise lived within its means. So it is fair to ask, what would higher education do with a windfall? Would new revenues go immediately to address these delayed needs, or would they be made available for funding such new initiatives as more distance education programs?

\section{METHODOLOGY}

This research can best be described as policy research. Policy research is "a mixture of science, craftlore, and art. The science is the body of theory, concepts, and methodological principles; the craftlore, the set of workable techniques, rules of thumb, and standard operating procedures; the art, the pace, style, and manner in which one works" [9, p. 173]. As implied by this quote, there is no one way to do policy research and therefore, practitioners use a number of methodologies. The chosen methodology for this study can best be described as "focused synthesis" [10, p. 59], which depends on a synthesis of various information sources to develop policy recommendations. While focused synthesis is somewhat like a literature review that draws on existing research studies, it is different from literature reviews in three ways. First, the focused synthesis may go beyond the literature review's identification of the literatureits gaps and understandings - to develop answers to specific questions. Second, it can also include unpublished research and third, it focuses on providing results or answers for the analysis, when a literature review is often the beginning of research.

Focused synthesis uses deductive reasoning and analysis, draws upon a variety of sources (including data and informed opinion), and is largely recursive. In other words, it synthesizes information to develop various understandings of a problem that, in turn, become more nuanced and comprehensive as the analysis proceeds. The goal is not to design a study to answer a question, as in traditional research, but to add to our understanding of an issue by taking a variety of viewpoints as captured in existing data and 
If Higher Education is a Right, and Distance Education is the Answer, Then Who Will Pay?

help forge a new understanding that incorporates the individual viewpoints and holds them to form a more comprehensive view of the issue.

Traditional questions of reliability and validity depend on the ability of the researcher to explain the data and provide transparent reasoning about the data as well as the limits of existing data and/or holes in the reasoning for which no data are yet available. Readers can judge whether this is done well or convincingly. Because policy research is dependent upon data and policy questions that are tied to a certain time and condition in society, it is often difficult to generalize to other eras or issues.

This research will draw on a number of data sources to answer the first research question. These include Grapevine (a national database on state tax appropriations for the general operation of higher education, collected and maintained by Illinois State University) [11], National Association of State Budget Officers (Fiscal Survey of the States for 2006) [12], SHEEO (State Higher Education Finance for 2005) [13], Western Interstate Commission on Higher Education [14], and the National Center for Higher Education Management Systems (NCHEMS) [15]. These data sources will be fundamental in analyzing the ability of states to appropriate funds to support current and projected higher education needs. This will give a partial answer to the first question: whether state governments can afford to support a "right to higher education.”

To attempt a partial answer to the second question-whether public higher education institutions can selffund such an initiative-the research literature on cost-efficiencies of online learning will be reviewed. Can online learning generate sufficient cost-efficiencies to help fund this initiative? What are the limits and/or likelihood this will occur?

\section{RESULTS}

\section{A. Can States Pay?}

To answer this question, we will need to review a number of analyses of the state resources available to public higher education. These analyses describe a public higher education sector that may be ill-suited to fund new initiatives from state coffers. The first set of data in Table 1 captures changes in the level of state appropriations to higher education for one year (FY06 to FY07), two years (FY 05 to FY 07), and five years (FY02 to FY07) [11]. This table captures a relatively positive picture in the most recent timeframe (FY06 to FY07) for all of the states (except for Montana and New Jersey where appropriations declined and North Dakota where appropriations did not change). The two-year change (FY05 to FY07) reveals a universally positive growth rate. But the five-year change (FY02 to FY07) reveals much smaller growth in 40 states (five of these states had less than $1 \%$ growth over the five-year period), double-digit growth only in Nevada, and negative changes in Colorado, Illinois, Michigan, Missouri, West Virginia, and Wisconsin. These figures capture a recent recovery of funding growth, but it is a recovery of funding that was either cut or stalled in the intervening years. In other words, single-digit growth in appropriations over five years may not mean that higher education institutions are flush with extra resources.

Table 1. Percent Growth in State Appropriations to Higher Education, 1-, 2-, and 5-year Changes

\begin{tabular}{|l|c|c|c|}
\hline State & $\begin{array}{c}\text { FY06-FY07 } \\
\text { 1-Year Change (\%) }\end{array}$ & $\begin{array}{c}\text { FY05-FY07 } \\
\text { 2-Year Change (\%) }\end{array}$ & $\begin{array}{c}\text { FY02-FY07 } \\
\text { 5-Year Change (\%) }\end{array}$ \\
\hline Alabama & 18.7 & 37.5 & 8.6 \\
\hline Alaska & 13.2 & 21.4 & 6.9 \\
\hline Arizona & 11.2 & 20.0 & 4.7 \\
\hline
\end{tabular}


If Higher Education is a Right, and Distance Education is the Answer, Then Who Will Pay?

\begin{tabular}{|c|c|c|c|}
\hline Arkansas & 6.6 & 14.6 & 4.8 \\
\hline California & 6.9 & 20.1 & 3.0 \\
\hline Colorado & 13.9 & 16.3 & -1.6 \\
\hline Connecticut & 6.1 & 12.0 & 3.3 \\
\hline Delaware & 7.9 & 14.6 & 4.6 \\
\hline Florida & 6.9 & 12.3 & 6.4 \\
\hline Georgia & 5.8 & 14.5 & Not Comparable \\
\hline Hawaii & 9.2 & 22.9 & 7.6 \\
\hline Idaho & 3.9 & 11.9 & 2.5 \\
\hline Illinois & 5.7 & 3.9 & -0.7 \\
\hline Indiana & 1.9 & 2.8 & 2.0 \\
\hline Iowa & 3.1 & 8.2 & 0.5 \\
\hline Kansas & 4.5 & 10.2 & 2.1 \\
\hline Kentucky & 3.8 & 11.9 & 3.8 \\
\hline Louisiana & 14.3 & 14.2 & Not Comparable \\
\hline Maine & 4.4 & 6.6 & 1.7 \\
\hline Maryland & 13.2 & 22.2 & 2.6 \\
\hline Massachusetts & 3.1 & 8.7 & 0.0 \\
\hline Michigan & 3.1 & 6.5 & -1.6 \\
\hline Minnesota & 2.6 & 10.0 & 0.4 \\
\hline Mississippi & 13.6 & 15.2 & 3.5 \\
\hline Missouri & 2.7 & 2.0 & -1.9 \\
\hline Montana & -0.7 & 12.5 & 2.9 \\
\hline Nebraska & 4.1 & 13.4 & 2.1 \\
\hline Nevada & 6.6 & 15.3 & 11.9 \\
\hline New Hampshire & 5.8 & 7.5 & 2.9 \\
\hline New Jersey & -2.7 & 5.0 & 2.5 \\
\hline New Mexico & 11.2 & 16.8 & 5.4 \\
\hline New York & 10.8 & 20.1 & 6.3 \\
\hline North Carolina & 13.9 & 26.5 & 6.8 \\
\hline North Dakota & 0.0 & 6.7 & 1.5 \\
\hline Ohio & 3.0 & 3.5 & 0.9 \\
\hline Oklahoma & 13.9 & 24.9 & 4.0 \\
\hline Oregon & 4.2 & 11.0 & 1.2 \\
\hline Pennsylvania & 5.2 & 6.9 & 1.4 \\
\hline Rhode Island & 3.1 & 6.4 & 1.1 \\
\hline South Carolina & 8.8 & 18.6 & 0.9 \\
\hline South Dakota & 5.5 & 7.9 & 4.2 \\
\hline Tennessee & 6.7 & 10.6 & 3.0 \\
\hline Texas & 4.1 & 13.7 & 1.3 \\
\hline Utah & 3.5 & 10.4 & 2.3 \\
\hline Vermont & 3.9 & 7.9 & 3.6 \\
\hline Virginia & 16.4 & 25.4 & 3.2 \\
\hline Washington & 6.2 & 15.4 & 3.6 \\
\hline West Virginia & 11.7 & 8.8 & -0.1 \\
\hline Wisconsin & 4.0 & 6.7 & -0.2 \\
\hline
\end{tabular}




\begin{tabular}{|l|c|c|c|}
\hline Wyoming & 10.1 & 21.2 & 10.0 \\
\hline US Average & 7.1 & 14.4 & 2.9 \\
\hline
\end{tabular}

SOURCE: Tables 1, 2, and 4 from [11] (http://www.grapevine.ilstu.edu/tables/index.htm)

However, total appropriations cannot fully capture the amount or health of state funding since it does not account for the number of students served. A better measure would be dollars appropriated per FTE student, resulting in a ratio that captures the average amount of money available to educate a student. Table 2 presents data from [15] that profiles the state and local support for higher education per FTE student in 3 years $(2000,2003$, and 2006). These three years were chosen because 2006 was the most recent year for which data were available, and 2000 and 2003 were chosen only because they were equidistant (i.e., in three-year intervals). For 19 states, the year 2000 was the highest ratio; for 29 states, the year 2006 was the highest ratio (only two states had their highest ratio in 2003). Only seven states saw increases in each of these three years; six states saw decreases in each year; the remainder hit the lowest ratio in 2003. Mirroring the majority of states that bottomed out in 2003, the U.S. average of state and local support for public higher education in 2000 per FTE student was \$6001; this figure declined to $\$ 5892$ in 2003 but increased to \$6325 in 2006 [15]. Data from [13] confirms these findings; from FY01 to FY06, 43 of 50 states decreased the per student appropriations to higher education [p. 12].

Table 2. State and Local Support for Public Higher Education, 2000, 2003, 2006 (Average Dollars per FTE Student)

\begin{tabular}{|c|c|c|c|}
\hline State & 2000 & 2003 & 2006 \\
\hline Alabama & 4889 & 4724 & 5617 \\
\hline Alaska & 9903 & 10778 & 12097 \\
\hline Arizona & 5677 & 5368 & 6316 \\
\hline Arkansas & 5412 & 5055 & 5899 \\
\hline California & 5805 & 6299 & 6586 \\
\hline Colorado & 4233 & 3405 & 3364 \\
\hline Connecticut & 9433 & 9272 & 9503 \\
\hline Delaware & 5761 & 5611 & 6632 \\
\hline Florida & 5617 & 4690 & 5641 \\
\hline Georgia & 9450 & 6992 & 7824 \\
\hline Hawaii & 8835 & 8802 & 10893 \\
\hline Idaho & 8294 & 6273 & 7303 \\
\hline Illinois & 8906 & 6968 & 6689 \\
\hline Indiana & 5436 & 5054 & 5390 \\
\hline Iowa & 6554 & 5681 & 5809 \\
\hline Kansas & 6126 & 5759 & 5792 \\
\hline Kentucky & 6739 & 6319 & 6753 \\
\hline Louisiana & 4815 & 5279 & 5583 \\
\hline Maine & 6354 & 6274 & 6096 \\
\hline Maryland & 5212 & 7002 & 6427 \\
\hline Massachusetts & 8195 & 7874 & 8372 \\
\hline Michigan & 6407 & 6377 & 5799 \\
\hline Minnesota & 6877 & 5719 & 5907 \\
\hline Mississippi & 6233 & 5027 & 5053 \\
\hline Missouri & 6484 & 5686 & 5846 \\
\hline Montana & 3757 & 3749 & 4409 \\
\hline
\end{tabular}


If Higher Education is a Right, and Distance Education is the Answer, Then Who Will Pay?

\begin{tabular}{|l|c|c|c|}
\hline Nebraska & 5151 & 5843 & 6999 \\
\hline Nevada & 5978 & 6326 & 8919 \\
\hline New Hampshire & 3337 & 3325 & 3193 \\
\hline New Jersey & 8172 & 8485 & 8145 \\
\hline New Mexico & 8167 & 8073 & 9299 \\
\hline New York & 6650 & 6721 & 7784 \\
\hline North Carolina & 7197 & 6894 & 4522 \\
\hline North Dakota & 4788 & 4636 & 4683 \\
\hline Ohio & 5443 & 4767 & 5638 \\
\hline Oklahoma & 5678 & 5630 & 4466 \\
\hline Oregon & 5088 & 4366 & 5660 \\
\hline Pennsylvania & 6020 & 5631 & 6413 \\
\hline Rhode Island & 5988 & 6328 & 5822 \\
\hline South Carolina & 4658 & 4492 & 4499 \\
\hline South Dakota & 4268 & 4237 & 6275 \\
\hline Tennessee & 4833 & 5329 & 6276 \\
\hline Texas & 5387 & 5312 & 5941 \\
\hline Utah & 5357 & 5101 & 3030 \\
\hline Vermont & 2754 & 3005 & 5223 \\
\hline Virginia & 5473 & 4814 & 6437 \\
\hline Washington & 5522 & 5556 & 4181 \\
\hline West Virginia & 4219 & 4529 & 6226 \\
\hline Wisconsin & 6147 & 6435 & 13425 \\
\hline Wyoming & 9037 & 11309 & 6325 \\
\hline US Average & 6001 & 5892 & \\
\hline
\end{tabular}

SOURCE: [15]

Another way to analyze the ability of states to tax themselves is to analyze the level of state and local support for higher education per $\$ 1000$ of personal income. Table 3 presents this information for the 50 states for the same 3 years as in Table 2 (i.e., 2000, 2003, 2006) [15]. These figures lead to several insights. But first it is important to note that the absolute numbers reflect the different economies or sources of wealth in the different states; therefore, it is difficult to compare across states, but best to focus on changes in a state's rate over time. Often, poorer states tax at a higher per capita rate because there are fewer sources of business income within the state; this may explain the relatively high rate in New Mexico, North Dakota, Wyoming, and other states. In any case, the three years of data reveal similar trends as in Table 2; 24 states experienced a consistent decline over the three years, only four states consistently increased this rate. What is also helpful to note is the year in which the state had its highest rate of taxation; for 33 states, 2000 was the highest year, for 10 states, 2003 was the highest year, and for seven states, the highest year was 2006. The U.S. average state and local support per $\$ 1000$ of personal income declined steadily, from 8.14 in 2000 to 7.91 in 2003 to 7.62 in 2006 [13, 15]. These figures capture a general decline in states' willingness to tax its population to support higher education and while some states are improving this rate, most are not. In another analysis [13, p. 19], the states' effective tax rate (state and local tax revenue per capita divided by total taxable resources per capita) decreased by $4.7 \%$ (from $8.18 \%$ in 1994 to $7.79 \%$ in 2004 ). 
If Higher Education is a Right, and Distance Education is the Answer, Then Who Will Pay?

Table 3. State and Local Support for Higher Education Operating Expenses per $\$ 1000$ of Personal Income, 2000, 2003, 2006

\begin{tabular}{|c|c|c|c|}
\hline State & 2000 & 2003 & 2006 \\
\hline Alabama & 10.96 & 10.22 & 10.43 \\
\hline Alaska & 10.01 & 10.22 & 10.75 \\
\hline Arizona & 9.55 & 8.46 & 8.54 \\
\hline Arkansas & 10.82 & 9.92 & 10.38 \\
\hline California & 9.49 & 10.16 & 9.15 \\
\hline Colorado & 5.52 & 4.21 & 3.67 \\
\hline Connecticut & 5.35 & 5.13 & 4.99 \\
\hline Delaware & 7.78 & 6.86 & 6.92 \\
\hline Florida & 6.31 & 5.31 & 5.76 \\
\hline Georgia & 9.02 & 9.43 & 9.28 \\
\hline Hawaii & 10.48 & 10.16 & 10.49 \\
\hline Idaho & 10.39 & 9.81 & 8.94 \\
\hline Illinois & 8.28 & 8.13 & 7.16 \\
\hline Indiana & 7.92 & 7.69 & 7.32 \\
\hline Iowa & 11.67 & 9.86 & 8.75 \\
\hline Kansas & 11.23 & 10.28 & 10.39 \\
\hline Kentucky & 10.12 & 10.29 & 10.22 \\
\hline Louisiana & 10.04 & 10.61 & 11.56 \\
\hline Maine & 6.64 & 6.50 & 6.04 \\
\hline Maryland & 7.32 & 7.16 & 6.49 \\
\hline Massachusetts & 4.67 & 4.58 & 4.41 \\
\hline Michigan & 8.67 & 8.55 & 7.61 \\
\hline Minnesota & 8.78 & 7.93 & 7.13 \\
\hline Mississippi & 15.17 & 12.15 & 11.23 \\
\hline Missouri & 7.57 & 6.53 & 5.92 \\
\hline Montana & 7.27 & 6.54 & 6.53 \\
\hline Nebraska & 10.86 & 11.67 & 11.12 \\
\hline Nevada & 5.42 & 5.68 & 7.02 \\
\hline New Hampshire & 2.71 & 2.46 & 2.33 \\
\hline New Jersey & 5.80 & 5.62 & 5.83 \\
\hline New Mexico & 15.22 & 15.75 & 16.77 \\
\hline New York & 6.70 & 6.93 & 7.40 \\
\hline North Carolina & 11.67 & 11.27 & 11.99 \\
\hline North Dakota & 12.37 & 12.17 & 10.81 \\
\hline Ohio & 7.03 & 6.53 & 6.14 \\
\hline Oklahoma & 10.58 & 9.60 & 8.69 \\
\hline Oregon & 6.57 & 6.59 & 5.67 \\
\hline Pennsylvania & 5.75 & 5.47 & 4.96 \\
\hline Rhode Island & 5.32 & 5.16 & 4.99 \\
\hline South Carolina & 9.12 & 7.80 & 8.55 \\
\hline South Dakota & 7.18 & 7.30 & 6.62 \\
\hline Tennessee & 7.01 & 7.25 & 7.06 \\
\hline Texas & 9.44 & 9.04 & 8.72 \\
\hline
\end{tabular}


If Higher Education is a Right, and Distance Education is the Answer, Then Who Will Pay?

\begin{tabular}{|l|c|c|c|}
\hline Utah & 10.59 & 10.58 & 10.16 \\
\hline Vermont & 3.99 & 4.16 & 4.02 \\
\hline Virginia & 7.29 & 5.96 & 5.66 \\
\hline Washington & 7.05 & 6.97 & 6.93 \\
\hline West Virginia & 10.27 & 9.95 & 8.81 \\
\hline Wisconsin & 9.14 & 9.35 & 8.16 \\
\hline Wyoming & 15.48 & 17.28 & 17.06 \\
\hline US Average & 8.14 & 7.91 & 7.62 \\
\hline
\end{tabular}

SOURCE: [15]

For FY07, 46 states saw their revenues increase. What did they do with a windfall in revenue? Twentyfour states adopted tax and fee decreases totaling \$2.1 billion [12, p. 8], in effect returning excess revenue to taxpayers or lowering fees for the future. So one has to ask, does the future look better? Table 4 presents data that may answer this question. By projecting out to 2013 using economic forecasts by Economy.com, population projections from the U.S. Census Bureau, and enrollment projections from the National Center for Education Statistics, a calculation can be made of the projected budget surplus (or gap) as a percent of revenue [15] for each state. Boyd [16], who prepared this state-by-state analysis, used fiscal year 2000 as the base year, and incorporated demographic and economic forecasts, revenue structures for each state, and assumptions about the rate of growth in taxes and price of government purchases (e.g., Medicaid, K-12). Individuals interested in all of the assumptions included in these estimates should review the original report [16]. The U.S. average gap in revenue by 2013 is -5.73 and no state had a positive projection [15]. In an attempt to understand changes in spending for higher education and all programs needed to maintain current services for the year 2013, the U.S. average ratio of spending for higher education to all other state services is -0.60 , and only four states had a positive ratio [16].

Table 4. Projected Surplus (Gap) as Percent of Revenue, 2013

\begin{tabular}{|l|c|}
\hline State & Gap as Percent of Baseline Revenue, 2005 to 2013 \\
\hline Alabama & -10.67 \\
\hline Alaska & -5.69 \\
\hline Arizona & -5.14 \\
\hline Arkansas & -4.16 \\
\hline California & -6.24 \\
\hline Colorado & -4.42 \\
\hline Connecticut & -3.82 \\
\hline Delaware & -0.97 \\
\hline Florida & -6.82 \\
\hline Georgia & -5.24 \\
\hline Hawaii & -5.30 \\
\hline Idaho & -6.87 \\
\hline Illinois & -5.56 \\
\hline Indiana & -6.47 \\
\hline lowa & -6.34 \\
\hline Kansas & -3.91 \\
\hline Kentucky & -4.77 \\
\hline Louisiana & -10.51 \\
\hline Maine & -1.55 \\
\hline Maryland & -2.05 \\
\hline
\end{tabular}


If Higher Education is a Right, and Distance Education is the Answer, Then Who Will Pay?

\begin{tabular}{|c|c|}
\hline Massachusetts & -2.33 \\
\hline Michigan & -4.77 \\
\hline Minnesota & -4.39 \\
\hline Mississippi & -9.81 \\
\hline Missouri & -7.44 \\
\hline Montana & -5.75 \\
\hline Nebraska & -4.28 \\
\hline Nevada & -9.25 \\
\hline New Hampshire & -0.48 \\
\hline New Jersey & -0.99 \\
\hline New Mexico & -5.92 \\
\hline New York & -5.22 \\
\hline North Carolina & -6.67 \\
\hline North Dakota & -3.34 \\
\hline Ohio & -3.01 \\
\hline Oklahoma & -4.29 \\
\hline Oregon & -8.16 \\
\hline Pennsylvania & -5.57 \\
\hline Rhode Island & -5.73 \\
\hline South Carolina & -6.98 \\
\hline South Dakota & -6.99 \\
\hline Tennessee & -9.33 \\
\hline Texas & -8.89 \\
\hline Utah & -5.83 \\
\hline Vermont & -2.88 \\
\hline Virginia & -4.17 \\
\hline Washington & -7.99 \\
\hline West Virginia & -4.75 \\
\hline Wisconsin & -2.83 \\
\hline Wyoming & -12.91 \\
\hline US Average & -5.73 \\
\hline
\end{tabular}

SOURCE: [15]

Combine this gloomy forecast with estimates of various pressures for increased service from higher education (see Table 6). Enrollments in public higher education have grown from 9.45 million in Fall 1980 to 13.28 million in Fall 2005; this growth is over 40\% [17]. High school graduates in the U.S. are projected to grow 11.1\% from 2002 to 2018; this growth is largely regional, with higher growth rates in the west (e.g., 102.6\% in Nevada and 55.4\% in Arizona) and south (e.g., 45.4\% in Georgia and 33.2\% in North Carolina) and population losses in the north and midwest (e.g., -30.6\% in North Dakota and -7.4 in Iowa) and east (e.g., -2.0\% in New York and -21.6\% in Vermont) [15]. There are exceptions to regional tendencies, such as $4.6 \%$ growth in Connecticut and $-24.9 \%$ loss in Wyoming.

Table 6. Projections of High School Graduates, 2002 to 2018

\begin{tabular}{|l|c|}
\hline State & Percent Change from 2001-02 to 2017-18 \\
\hline Alabama & 4.1 \\
\hline Alaska & 0.9 \\
\hline Arizona & 55.4 \\
\hline
\end{tabular}


If Higher Education is a Right, and Distance Education is the Answer, Then Who Will Pay?

\begin{tabular}{|c|c|}
\hline Arkansas & 5.5 \\
\hline California & 9.5 \\
\hline Colorado & 39.4 \\
\hline Connecticut & 4.6 \\
\hline Delaware & 16.7 \\
\hline Florida & 29.8 \\
\hline Georgia & 45.4 \\
\hline Hawaii & -10.9 \\
\hline Idaho & 17.3 \\
\hline Illinois & 5.8 \\
\hline Indiana & 25.7 \\
\hline Iowa & -7.4 \\
\hline Kansas & 1.1 \\
\hline Kentucky & 7.0 \\
\hline Louisiana & -11.9 \\
\hline Maine & -13.6 \\
\hline Maryland & 12.6 \\
\hline Massachusetts & -0.2 \\
\hline Michigan & 3.9 \\
\hline Minnesota & 0.7 \\
\hline Mississippi & -1.1 \\
\hline Missouri & -0.4 \\
\hline Montana & -19.5 \\
\hline Nebraska & -1.1 \\
\hline Nevada & 102.8 \\
\hline New Hampshire & -4.2 \\
\hline New Jersey & 16.0 \\
\hline New Mexico & -7.0 \\
\hline New York & -2.0 \\
\hline North Carolina & 33.2 \\
\hline North Dakota & -30.2 \\
\hline Ohio & 0.5 \\
\hline Oklahoma & -1.8 \\
\hline Oregon & 7.6 \\
\hline Pennsylvania & -6.0 \\
\hline Rhode Island & 8.9 \\
\hline South Carolina & 18.8 \\
\hline South Dakota & -15.4 \\
\hline Tennessee & 1.8 \\
\hline Texas & 29.7 \\
\hline Utah & 30.8 \\
\hline Vermont & -21.6 \\
\hline Virginia & 17.8 \\
\hline Washington & 8.5 \\
\hline West Virginia & -8.2 \\
\hline Wisconsin & -4.2 \\
\hline
\end{tabular}




\begin{tabular}{|l|c|}
\hline Wyoming & -24.9 \\
\hline US Average & 11.1 \\
\hline
\end{tabular}

SOURCES: $[14,15]$

The figures in Table 6 on high school graduates mirror the population projections from 2000 to 2025 (see Table 7) where the U.S. average growth is $14.1 \%$ [15]. Population growth is also largely regional, with higher growth in the west (e.g., $74.1 \%$ in Nevada and $67.3 \%$ in Arizona) and south (e.g., 36.2\% in Georgia and $41.8 \%$ in North Carolina) and population declines in the north and midwest (e.g., -22.6\% in North Dakota and $-16.3 \%$ in Iowa) and east (e.g, $-4.1 \%$ in New York and $-9.4 \%$ in Vermont. There are, again, exceptions to these trends, such as $3.9 \%$ growth in Connecticut and $-10.7 \%$ loss in Mississippi. While the oncoming boom in higher education enrollments is largely regional or particular to a specific state, the transient nature of traditional-age college students makes it difficult to conclude that a state losing population (such as New York) will necessarily feel the pinch. However, it is fair to note that the majority of college students do remain in their home states, so population growth (or the lack thereof) should impinge on both college enrollments and the state's ability to tax its population to support its various state services, such as higher education.

Table 7. 18 to 24 Year Olds Population Growth, 2000 to 2025

\begin{tabular}{|l|c|}
\hline State & $\begin{array}{c}\text { Population Projection 2000 to 2025 } \\
\text { (Percent Change) }\end{array}$ \\
\hline Alabama & -5.6 \\
\hline Alaska & 35.9 \\
\hline Arizona & 67.3 \\
\hline Arkansas & 6.1 \\
\hline California & 19.9 \\
\hline Colorado & 26.4 \\
\hline Connecticut & 3.9 \\
\hline Delaware & 3.4 \\
\hline Florida & 48.4 \\
\hline Georgia & 36.2 \\
\hline Hawaii & 26.4 \\
\hline Idaho & 10.0 \\
\hline Illinois & 0.1 \\
\hline Indiana & 0.6 \\
\hline lowa & -16.3 \\
\hline Kansas & -4.6 \\
\hline Kentucky & 1.2 \\
\hline Louisiana & -4.8 \\
\hline Maine & -16.7 \\
\hline Maryland & 31.6 \\
\hline Massachusetts & 6.4 \\
\hline Michigan & -5.0 \\
\hline Minnesota & 9.8 \\
\hline Mississippi & -10.7 \\
\hline Missouri & 3.5 \\
\hline Montana & -16.7 \\
\hline Nebraska & -3.7 \\
\hline Nevada & 74.1 \\
\hline
\end{tabular}


If Higher Education is a Right, and Distance Education is the Answer, Then Who Will Pay?

\begin{tabular}{|l|c|}
\hline New Hampshire & 6.9 \\
\hline New Jersey & 9.5 \\
\hline New Mexico & -9.7 \\
\hline New York & -4.1 \\
\hline North Carolina & 41.8 \\
\hline North Dakota & -22.6 \\
\hline Ohio & -6.9 \\
\hline Oklahoma & 2.6 \\
\hline Oregon & 15.2 \\
\hline Pennsylvania & -7.0 \\
\hline Rhode Island & -6.6 \\
\hline South Carolina & 9.6 \\
\hline South Dakota & -15.6 \\
\hline Tennessee & 19.0 \\
\hline Texas & 38.9 \\
\hline Utah & 23.2 \\
\hline Vermont & -9.4 \\
\hline Virginia & 32.6 \\
\hline Washington & 22.3 \\
\hline West Virginia & -22.9 \\
\hline Wisconsin & -6.1 \\
\hline Wyoming & -22.8 \\
\hline US Average & 14.1 \\
\hline SOURC: & \\
\hline
\end{tabular}

SOURCE: [15]

A corollary to the situation with states (fewer resources, greater demand for services) is the economic situation of families. This is referred to as "affordability," and is captured in Table 8 as percentage of family income needed to pay for college at public four-year institutions for two years, 2001 and 2005. Individuals interested in this ratio for other types of institutions, other years, or broken down by income quintile can find this information at [15]. In 49 states, the percentage of family income needed to pay for college increased, as did the national average from $24.2 \%$ in 2001 to $30.7 \%$ in 2005 . In only one state (Hawaii), did the percentage decline between the two years. This situation is the result of several influences, not least of which are states' increasing reliance on tuition and tuition increases to raise the resources needed by higher education to address enrollment demands and increasing costs.

Table 8. Percentage of Family Income Needed to Pay for College at Public Four-Year Institutions

\begin{tabular}{|l|c|c|}
\hline State & $\begin{array}{c}2001 \\
\text { Percentage }\end{array}$ \\
\hline Alabama & 23.3 & 2005 \\
\hline Alaska & 21.1 & 24.5 \\
\hline Arizona & 25.5 & 31.4 \\
\hline Arkansas & 19.9 & 25.3 \\
\hline California & 28.2 & 33.5 \\
\hline Colorado & 20.0 & 26.9 \\
\hline Connecticut & 24.7 & 32.7 \\
\hline Delaware & 29.3 & 33.3 \\
\hline Florida & 22.8 & 25.8 \\
\hline Georgia & 18.4 & 23.2 \\
\hline
\end{tabular}


If Higher Education is a Right, and Distance Education is the Answer, Then Who Will Pay?

\begin{tabular}{|c|c|c|}
\hline Hawaii & 24.2 & 21.0 \\
\hline Idaho & 19.6 & 21.4 \\
\hline Illinois & 23.0 & 35.4 \\
\hline Indiana & 24.5 & 30.1 \\
\hline lowa & 19.4 & 30.3 \\
\hline Kansas & 19.1 & 25.6 \\
\hline Kentucky & 18.9 & 29.8 \\
\hline Louisiana & 21.3 & 23.5 \\
\hline Maine & 25.3 & 36.5 \\
\hline Maryland & 24.9 & 31.5 \\
\hline Massachusetts & 24.8 & 34.4 \\
\hline Michigan & 25.6 & 35.7 \\
\hline Minnesota & 17.5 & 25.6 \\
\hline Mississippi & 22.4 & 26.3 \\
\hline Missouri & 21.5 & 30.6 \\
\hline Montana & 26.2 & 33.3 \\
\hline Nebraska & 21.9 & 27.3 \\
\hline Nevada & 22.9 & 28.0 \\
\hline New Hampshire & 28.8 & 32.5 \\
\hline New Jersey & 27.5 & 36.6 \\
\hline New Mexico & 22.6 & 27.5 \\
\hline New York & 29.8 & 32.8 \\
\hline North Carolina & 19.9 & 26.4 \\
\hline North Dakota & 20.2 & 27.8 \\
\hline Ohio & 28.9 & 42.4 \\
\hline Oklahoma & 17.2 & 24.2 \\
\hline Oregon & 29.3 & 35.5 \\
\hline Pennsylvania & 29.6 & 39.2 \\
\hline Rhode Island & 34.9 & 38.6 \\
\hline South Carolina & 25.8 & 36.0 \\
\hline South Dakota & 20.1 & 26.9 \\
\hline Tennessee & 23.6 & 26.3 \\
\hline Texas & 24.2 & 30.2 \\
\hline Utah & 16.2 & 18.4 \\
\hline Vermont & 37.7 & 41.0 \\
\hline Virginia & 20.7 & 27.5 \\
\hline Washington & 22.6 & 31.0 \\
\hline West Virginia & 25.9 & 30.7 \\
\hline Wisconsin & 18.4 & 25.9 \\
\hline Wyoming & 20.1 & 23.3 \\
\hline US Average & 24.2 & 30.7 \\
\hline
\end{tabular}

\section{SOURCE: [15]}

There is one question remaining: Can online learning address the need for increased access in the states where the population or the number of high school graduates is growing? Enrollments in online courses in fall 2003 were 1.9 million students, having grown 20\% from fall 2002 [18], which grew to 3.2 million 
If Higher Education is a Right, and Distance Education is the Answer, Then Who Will Pay?

students in fall 2005 [19]. While the growth rate of online enrollments is impressive, is there sufficient capacity to address some states' need for increased access to higher education?

An answer to this question may result from translating growth rates into actual figures. The U.S. will see a growth in high school graduates from 2001-02 (2.9 million graduates per year) to 2017-18 (3.2 million graduates per year) $[14,15]$. Assuming all or most of these graduates go on to college somewhere, this is a rough estimate of the increased access that higher education must provide. There is also increased access for non-high-school graduates - mostly adults - which is more difficult to estimate. The U.S. population of 18- to 24-year olds is expected to grow by 3.8 million individuals from the year 2000 to 2025; the proportion of these who return to college is different in each state, but averaged $65 \%$ nationwide in 1992 [20]. If that rate stays the same, an approximate 2.5 million individuals aged 18 to 24 may want to return to college by 2025. Certainly, the number of adults beyond age 24 desiring to return to college increases that number substantially. These calculations are clearly approximate and should be understood to be rough estimates, but they do indicate that the number of individuals wanting higher education may be beyond the current capacity of online courses to satisfy. Obviously, online courses will increase in number and capacity in the next two decades, but will their capacity address the total need (from high school graduates and adults) for access to higher education? This is a conundrum that is impossible to estimate.

What these figures imply is that some states will have their proverbial hands full educating a growth in high school graduates and/or population growth within the level of resources likely to come to them from state coffers. Other states may have excess capacity to address the "right to higher education," but will they have the resources (remembering the resource gap projected for 2013 [15]) to do so? And if the states had the resources, would those go to higher education? In a 2002 national survey of the general public, respondents were asked how much of a priority the federal government should give to a number of issues. Table 9 replicates these results. Only 3\% of those surveyed selected "Ensuring every American can afford to send their children to college" [21] as "very high priority." While this question was directed to priorities of the federal government, and is not a perfect proxy for questions about the public's priorities for state funding, it does decidedly indicate that the public have several higher priorities for the use of tax resources rather than funding higher education.

Table 9. How Much of a Priority Should the Federal Government Give To...

\begin{tabular}{|l|c|c|}
\hline \% responding & Very High Priority & High Priority \\
\hline $\begin{array}{l}\text {...Ensuring every American has access to affordable } \\
\text { health care? }\end{array}$ & 39 \\
\hline ... Conserving natural resources? & 34 & 43 \\
\hline ...Setting academic standards for public schools? & 32 & 36 \\
\hline ...Providing decent standard of living for elderly? & 28 & 44 \\
\hline ...Reducing juvenile delinquency? & 28 & 32 \\
\hline ...Ensuring that food and medicines are safe? & 4 & 20 \\
\hline $\begin{array}{l}\text {...Ensuring every American can afford to send their } \\
\text { children to college? }\end{array}$ & 3 & 17 \\
\hline ...Reducing poverty? & 3 & 14 \\
\hline
\end{tabular}

SOURCE: [21]

So far, this analysis has resulted in a pessimistic view of public higher education's ability to address the right to higher education through the level of appropriations expected from the state. As with all projections, estimates have to be based on some assumptions, and the assumptions are most frequently based on "more of the same," or a projection of the future that is a linear extension of present day relationships. For example, more demands are being made on state resources from K-12 education, 
If Higher Education is a Right, and Distance Education is the Answer, Then Who Will Pay?

transportation, Medicare, prisons, and social services at the same time as citizens express displeasure (through tax or spending limitation initiatives or referenda) with the level of taxes paid. But what if state economies blossomed, recovering from the millennial slump of the tech industry, the impact of September $11^{\text {th }}$ on the airline industry, and the declining housing industry? What if citizens decided that taxes were a responsibility and not a burden? What if state legislatures came to view higher education as an essential investment for the future, and a critical element in a plan for economic recovery and/or health? These things could happen, but are essentially impossible to predict using the normal linear models. No analysis would be complete without recognizing that the future may be markedly different from the past or the projections represented in Tables 1-9 above. But the larger question is whether conclusions should be drawn on "what ifs" or what is known to be true today. Clearly, a positive future would be most welcome (and essential for personal well-being and a sense of hopefulness for the future), but it is difficult to impossible to depend upon or plan for. Should we plan for a turnaround of magical proportions, or plan for the worst while working on bringing about that turnaround? Perhaps the latter approach recognizes the individual's need to hope for a positive future while recognizing that the best evidence indicates a much more cautious understanding of what the future may bring.

While this analysis has focused on the role of state appropriations for funding increased access, there are other sources of funds that may be brought to bear on increasing access. First, public institutions may pursue the online market in the hope of bringing in excess funds that can be used to fund more online courses or other services. And certainly, if tuition charges exceed the cost of these programs, then this source of revenue may be a viable way to fund the right to education. Second, various grant programs may also be used to fund the development of new online programs, which takes the burden off the institution for funding this process. In other words, there may be other sources of funding, although these, too, may present problematic challenges. The first source of funding relies on the ability of students to fund the initiative, and may accentuate current problems with inequitable access to higher education based on family or personal income. The second source of income relies on the availability of alternative sources of funding which may dry up with changes in the economy or the goals of foundations.

The question for individuals working on the initiative to make higher education a right is whether the states can afford or will support such an increase in their institutions' service public. Absent a major change in the economy, state tax structures and willingness to fund higher education, and the public's willingness to tax itself, the answer may be "no."

\section{B. Can Efficiencies Pay?}

\section{Introduction}

The second question is whether-ignoring the question about state support for the interim-institutions could fund an expansion of distance education capacity by capitalizing on cost-efficiencies. In a review [22] of the research literature on methods for achieving cost-efficiencies through online learning, there was ample evidence that online learning could indeed achieve efficiencies. Cost savings were often substantial.

This question has benefited from a number of well-designed studies conducted as part of the Program in Course Redesign hosted through the National Center for Academic Transformation (NCAT) and led by Carol Twigg (http://www.thencat.org). These course redesigns used technology in some fashion, from putting courses or modules online to other types of technology-enhancements or even using a site-based technology lab. Other studies on costs of online education have been funded by the Mellon Foundation and the Sloan Foundation. And certainly there are other efforts that focus on saving costs or using resources more efficiently, such as projects like Great Plains IDEA (http://www.gpidea.org) and Open Educational Resources (and discussed more thoroughly in another article in this issue), whose best 
example is the MIT OpenCourseWare project (http://ocw.mit.edu). However, Twigg's effort produced the best information so far to answer the question of whether online learning can be sufficiently cost-efficient to pay for universal access to education. Therefore, this analysis relies on several figures taken from the Twigg studies.

With funding from Pew Charitable Trusts, 30 institutions received grants to redesign courses accompanied by a solid plan to lower costs and document improved student learning. Those 30 institutions reduced costs an average of $37 \%$, with some projects reducing costs by $15 \%$ and others by $77 \%$, and generated a savings of \$3.1 million per year in operating costs [23]. (More detailed information on the individual projects can be found at http://www.thencat.org/PCR.htm.) It is not clear whether such savings might be sustainable or possible to achieve in all parts of an institution's curriculum. This section will first focus on various strategies for producing these results-including the three substitutions of capital for labor, capital for capital, and lower-cost labor for higher-cost labor-and then review the benefits to student learning as well as cost-savings accruing from these redesigned courses. Finally, the principles of redesigning courses to achieve cost-efficiencies will be discussed.

\section{The Substitutions}

First, institutions substituted capital for labor by designing the course to use technologies rather than higher-cost faculty. Penn State decreased the time spent on lectures and increased the use of computermediated instruction; University of Central Florida used online modules; Brigham Young University used multimedia lessons; Virginia Tech created a physical math lab; Fairfield University replaced dissection labs with computer-based activities and decreased laboratory costs by 73\%; the University of TennesseeKnoxville reduced the cost to students of textbooks and other materials by customizing materials and offering online access to them [23, 24, 25, 26, 27]. Campbell et al. [28] described the use of virtual labs to teach electronics, resulting in lower cost per student and learning as good as physical labs plus higher student satisfaction with the more flexible virtual labs. The University of Central Florida used online quizzes to provide feedback to students as did Texas A\&M, which used an application that personalized problem sets, quizzes, and exams [29]. Arvan et al. [30] also used online quizzes to help students assess their own learning and identify what they needed to work on. The University of Buffalo used online grading and a course management system to reduce faculty time spent on recording, calculating, and storing grades, photocopying materials, posting changes, and sending out announcements [26].

In most of these cases, faculty time was redesigned, away from lecturing and grading quizzes and toward developing the redesigned course. Faculty positions were not eliminated from the institutional budget, but their talents used in new or different ways. In other cases, the redesign allowed the institution to reduce the number of faculty teaching a course in psychology statistics from five to one [29], or numerous sections taught by different instructors could be made more consistent in content and learning outcomes [27]. Class meeting time was reduced in lieu of both multimedia lessons and one-on-one meetings with writing faculty, which reduced faculty time by $25 \%$ and contributed to better papers (based on evaluations by three readers) in the online sections [27]. Not all institutions want to decrease the student's time spent directly with faculty, but others may find this rearrangement of faculty duties helpful.

A redesign can also allow an institution to make other changes. Fairfield University reduced the number of sections taught (thereby reducing the need for faculty) and increased the number of students in each section; Virginia Tech and the University of Southern Mississippi were also able to reduce the number of sections and increase enrollments. Penn State reduced the number of graduate assistants in its redesigned

course. The University of Illinois at Urbana-Champaign, Portland State University, and Florida Gulf Coast University increased the number of students per section as a result of their redesign efforts, 
If Higher Education is a Right, and Distance Education is the Answer, Then Who Will Pay?

although each of these projects included several additional changes (see details on these changes as well as many others at http://www.thencat.org/PlanRes/R2R CostRed.htm).

The capital-for-capital substitution is a subset of the substitution of capital for labor, but given the interest of many institutions in using online learning to use existing buildings more efficiently, these studies are discussed separately. Examples of capital-for-capital substitutions can be found in studies from the University of Central Florida (UCF), the University of Virginia, and Vanderbilt University. By delivering portions of a course online, UCF saved classroom space: two or three sections could be scheduled in the same classroom, saving the cost of building new space or renting space. In Milam's [31] description of costing decisions at the University of Virginia, the cost of renting local commercial space (\$25 per square foot per year) was incorporated. By recognizing a cost for space, Milam concluded that online courses represent no space cost to the institution, and traditional courses represent a space cost (with mixed-model courses carrying a moderate cost for space). Farmer (in [32]) estimated that the absence of a physical building would save up to $15 \%$ of the cost of traditional courses. Vanderbilt University used simulation software in sophomore-level electrical engineering and found that student learning in the simulated labs was as good as for students in the physical labs. Campbell et al. [28] conclude that this software could "replace some physical labs" (p. 9), which would also lower the ongoing cost of equipment and supplies for the physical labs.

Instructional design also allows for the substitution of lower-cost labor for the higher cost of faculty. This is not an argument for replacing full-time with part-time instructors in the absence of redesigning the course. Redesign incorporates the expertise of full-time faculty where higher-order learning is the goal, learning problems must be diagnosed, or complex projects evaluated and appropriate feedback occur. So this is an argument for using faculty expertise in a targeted manner, and using lower-cost labor when a lower level of expertise seems appropriate.

Again, the Course Redesign projects have several examples where creating online modules, virtual labs, computer-mediated exercises, online quizzes and tests, and automated grading helped the student learn more while using higher-cost faculty labor less. Obviously, these options also are a way to use capital (the designed instruction embedded in online or web-based settings) for labor, but where instructional support is still necessary, the design can be sufficiently robust so that the instructional support can be provided by lower-cost assistants. In this case, courses used graduate assistants, teaching assistants, undergraduate peers, and part-time instructional staff to answer technical questions, diagnose simple learning mistakes, or provide other assistance. Even lower-cost-faculty (such as assistant professors) can lower the cost of a course if the original designer was a full professor. Rio Salado College used a course assistant to answer non-math-related questions which accounted for $90 \%$ of the interactions with students [26]. Arvan et al. [30] described a set of courses at the University of Illinois that used graduate assistants to teach and undergraduate peer-tutors and peer-to-peer interaction to answer basic questions.

\section{The Benefits}

There are several benefits to using instructional design to put coursework wholly online or even partially online. Certainly, studies have found that grades improve [29], as do points on the mid-term exam, final exam, and other assessments of student knowledge of course content. At Penn State, students in the redesigned courses had 68\% correct answers (compared to 60\% correct answers for students in traditional courses); at Carnegie Mellon, students in redesigned statistics courses increased their performance by 22.8\%; at Florida Gulf Coast University, average scores on a standardized test were $85 \%$ of the total (compared to $70 \%$ for students in the traditional course); at the University of Iowa, students enrolled in a redesigned introductory chemistry course performed better on an American Chemical Society exam in 
two comparisons with students in the traditional course (65.4 to 58.4 and 61.0 to 52.4); at the University of Massachusetts-Amherst, exams in biology were redesigned so that $67 \%$ of the questions tested reasoning or problem-solving skills, which comprised only $23 \%$ of the questions in an earlier version of the test; at Drexel University and Carnegie Mellon, final exams were made more difficult as a consequence of the additional student learning resulting from course redesign [23, 24, 25]. At Michigan State University, students in a redesigned introductory physics course had an $11 \%$ increase in performance and 32\% of the students achieved grades higher than 3.5 (versus $18 \%$ in the traditional course) [29]. Arvan et al. [30] also found that the asynchronous learning network (ALN) courses boosted students' exam scores.

But students in redesigned courses also drop the course less often, fail at a lower rate, and withdraw less often. Twigg [24] calls this the drop-failure-withdrawal rate, or DFW rate. The University of Southern Maine lowered the DFW rate from $28 \%$ to $19 \%$ in its redesigned introductory psychology course. At Drexel University, the DFW rate for computer programming went from $49 \%$ to $38 \%$; at Florida Gulf Coast University, the rate dropped from $45 \%$ to $11 \%$; at Indiana University-Purdue University Indianapolis, the rate dropped from $39 \%$ to $25 \%$ in introductory sociology; at the University of New Mexico, the rate dropped from $42 \%$ to $25 \%$ in introductory psychology; Rio Salado College increased completion rates from 59\% to 64.8\% [24, 25, 26]. At Baruch College, a course in "College Literacy" for students with poor reading and writing skills had a failure rate of almost 50\%; when the course was redesigned, $75 \%$ of the students passed the course [33]. At the University of Idaho, the percent of students earning a D or failing grade was cut by more than half. Certainly, students will benefit from these improvements as will institutions that can improve the cost per passing student.

In other words, redesigned courses have "increased course-completion rates, improved retention, better student attitudes toward the subject matter, and increased student satisfaction with the new mode of instruction" [24, p. 24]. Improved learning is the result of changing the pedagogy and educational philosophy so that the course stresses active, experiential learning, including modules, tutorials, exercises, quizzes, as well as projects. In Penn State's redesign of elementary statistics, hands-on experience with data analysis and low-stakes "readiness assessment" testing involved students in their learning more directly and increased their motivation to learn [34]. In other words, active learning has its own rewards, and good instructional design simply uses this pedagogy to increase student engagement and learning. "Students learn math by doing math, not by listening to somebody talk about doing math" [24, p. 25].

\section{The Principles and Conditions}

According to Twigg [23], there are five redesign principles:

- Principle \#1: Redesign the whole course;

- Principle \#2: Encourage active learning;

- Principle \#3: Provide students with individualized instruction;

- Principle \#4: Build in on-going assessment and prompt (automated) feedback; and

- Principle \#5: Ensure sufficient time-on-task and monitor student progress (see http://www.thencat.org/PlanRes/R2R PrinCR.htm).

These principles are noticeably similar to Chickering and Gamson's [35] "Seven principles of good practice for undergraduate instruction." In any case, when a course is redesigned and/or put online, the principles for improving student learning online seem to be remarkably similar to those for improving learning in traditional courses; the advantage in terms of cost-efficiency is that the redesign can also rethink how faculty time is used and make the various substitutions that affect cost. 
The substitutions above work, however, under five conditions. First, redesign works well when enough students take the course to justify the expenditure of redesigning the course. These can be the 25 courses that comprise half the student enrollments at community colleges or one-third of the enrollments at colleges [24, 25], usually lower-division and introductory courses. Second, they can be the courses which, when repeated over enough semesters, enroll enough students to justify the expenditure of redesigning the course. Third, they can be the courses that — given their difficulty-act as a barrier to students continuing their studies. Fourth, the course must represent a fairly stable curriculum [36] that will not need to be continuously revised in subsequent offerings of the course. While modest revisions are the norm in any offering of an online course, it would be best if these were kept to a minimum. Fifth, Miller [36] mentions that "scope creep" (p. 166) - the tendency to over-build a course and add features that are nice but not required-must be avoided. In other words, institutions pursuing this route to cost-efficiencies need to monitor their instructional design efforts so that course design and revision do not go overboard.

There is an important sixth condition. Twigg [37] has emphasized that for course redesign to be effective, an institution must be ready. Eight “course readiness criteria” [37, p. 9-10] must be met:

- Improvements in the course potentially must have a high impact on the curriculum.

- The course must offer the possibility of capital-for-labor substitution.

- Decisions about curriculum in the department, program, or school must be made collectively-in other words, beyond the individual faculty member level.

- The faculty must be able and willing to incorporate existing curricular materials into the project in order to focus work on redesign issues rather than on materials creation.

- Project participants must have the requisite skills.

- The course's expected learning outcomes and a system for measuring their achievement must be identified.

- The faculty members involved must have a good understanding of learning theory or access to expert partners.

- In order for the innovation to be self-sustaining in the future, institutions must have a business plan to support the ongoing operation of the redesigned course.

This list of "readiness criteria" helps an institution decide if it can benefit from undertaking course redesign projects which would avoid the unready institution from undertaking a costly redesign that it cannot benefit from and cannot maintain. On the other hand, an institution that is ready to find ways to be cost-efficient and improve student learning can be assured that its investment in time, money, and people can have the payoff it wants.

Given the cost of the redesign process which may involve the technical and design skills of several professionals from programmers to instructional designers and faculty, is this investment always required? Courses at Washington State University that were redesigned using an instructional designer and those that did not were evaluated [38], and the course design process was found to increase facultystudent interaction, student-student interaction, feedback, and time-on-task. This is because many faculty are not familiar with the seven principles and by working with an instructional designer, they become not only more familiar with the principles, but more likely to integrate technology that use the practices indicated by the principles. But another study, also done at Washington State University [39], found that courses that went through a quick course review by instructional design professionals did as well as those that went through a long, formal design process. In other words, perhaps a more cursory review of online courses that uses the seven principles may be as effective as a more intensive development process. This finding argues for the importance of incorporating design principles in a short review process of online 
offerings, and perhaps using the more intensive process for courses that require more bells and whistles or for faculty development when they are new to the online course design process.

\section{Can Online Learning Increase Access?}

Can we conclude from this information that increased access can be provided through online learning? The answer may be yes, but a cautious yes, because the number of increased enrollments gained in this fashion may not be as large as is needed and they will require an investment to accomplish this objective. Let us take the Twigg studies [23, 24, 25, 26, 37] for an example. The project redesigned 30 courses (not all projects were courses, but let us assume this to be so for analysis purposes). If \$3.1 million were saved across 30 courses, that means approximately \$100,000 was saved per course. And in the case of these particular findings, the 30 institutions received $\$ 200,000$ (on average) per year in external funding to help with the process. Such funding levels are probably not to be expected from foundations or states in the future, so the redesign process will need to be funded by individual institutions. Twigg [23] estimates that if all higher education institutions in the U.S. redesigned their biggest 25 courses (the ones with the largest enrollments over time), the "cost of instruction would be reduced annually by approximately 16 percent-while improving student learning and retention" (p. 48). This figure, if an accurate assessment, would save approximately $\$ 11.5$ billion of the $\$ 72$ billion appropriated by states to public higher education for FY07 [11, Table 1]. Whether Twigg's estimate is generous or on target, there is certainly some amount of money to be saved from redesigning courses.

If Twigg's principles are essentially correct and the conditions for redesign are also sound, and there is no reason not to assume this to be so, then how many courses can be redesigned at each institution? Certainly, there are many introductory-level courses at community colleges and universities, but the likely penetration of redesigned courses will be different at a university that has many more specialized upperdivision and graduate courses than at a community college. To put a more positive spin on this estimate, if institutions only help faculty design online courses using the seven principles [35] or encourage instructional designers to review online courses and/or teach faculty how to prepare a better online course [39] but forego the more extensive effort of a course redesign, can reaching the $\$ 11.5$ billion target become more feasible? In any case, certainly the benefits in improved student learning and lowered dropfailure-withdrawal rates seem worth the effort and investment.

So can institutions fund a "right" to higher education? The answer is likely "yes," but only to a modest extent at first. If redesigning courses catches on, cost-efficiencies may make an important contribution to funding universal higher education, but only if the savings generated are applied to efforts to increase access and not reallocated for a number of other purposes. But for institutions in states with high growth rates in general population and high school graduates, they will be rightfully focused on using any funds saved or access increased to better serve states' needs. Online learning may well help address this demand. For institutions in low-growth states, capacity may exist, but then two issues intercede. Will institutions in low-growth states have sufficient funds to invest in designing online coursework and will they have the drive to undertake the redesign process in the absence of demands for access from the state's citizens? These are the imponderables that only individual institutions can answer. In other words, there appears to be a practical limit to what public higher education in the U.S. can do to address a universal right to higher education.

\section{DISCUSSION}

Let us return to several statements made in the preceding section and discuss the implications in terms of answers to the research questions, grouping the findings into positive and negative categories. First, can 
state governments in the United States afford to fund a universal right to higher education? Absent a thorough turnaround in state economies that generate additional resources in state coffers, a revamping of tax structures, and resurgence in citizens' willingness to tax themselves, this seems unlikely. For states that face an increase in high school graduates and population, the strain on state resources may worsen as demand for services of all types (e.g., K-12, Medicare, transportation) increase with the increase in population. If economic conditions in the state do not improve and resources available to state governments do not increase, states may continue to fund higher education last or expect higher education to raise its own resources by raising tuition, seeking other funding, or operating more efficiently.

Perhaps there is a more positive answer to the second research question, can public higher education institutions in the U.S. fund this initiative through capitalizing on cost-efficiencies of online learning? Certainly, there is some positive evidence that online learning, if properly designed, can generate some cost-efficiencies as well as improve student learning. These positive outcomes, however, will require some investment that will come-if not from the state-then from the institution. Higher education institutions may be motivated to find and allocate funds to this process if they can use the cost-savings to either fund new initiatives or further redesign efforts. This argues for not punishing the cost-efficient institution by removing resources, but allowing those resources to be used within the institution to pursue further economies that also improve student learning. This would clearly work in the states' favor.

In states where the number of high school graduates or general population is declining, higher education institutions can use their excess capacity to address the pressure for more access in states with growth. These states (Hawaii, Iowa, Louisiana, Maine, Montana, New Hampshire, New Mexico, New York, North Dakota, Oklahoma, Pennsylvania, South Dakota, Vermont, Wisconsin, and Wyoming) may be well situated to provide access through well-designed online learning to the residents in other states or countries, avoiding the need for students to pick up and move, which adult students may not be able to do. There are four barriers to this happening, however. First, with declining population may come a decline in state resources, making funding for higher education in these states problematic and lessening the likelihood that these states can address other states' needs for higher education. Second, designing online learning for cost-efficiency and better student learning takes resources, both in terms of people and time. If the state cannot assist with this transformation, then institutions have to be free to find the resources within their current operations to fund this process. Third, these institutions need to have the will to transform themselves (e.g., Twigg's "readiness criteria”). And fourth, institutions need to take a careful look at what it takes to be successful in the online marketplace and offer programs that are financially sustainable [30]. The perception held by many in the early days of online learning that money was to be made-lots of it-has been proven to be largely false. However, an institution's online offerings can provide a useful revenue stream that covers existing costs of programs and generates resources for redesigning more offerings. But it takes work. The hope and promise of such revenue may be motivation enough for institutions to undertake the serious work of redesigning courses so that they can be offered online, efficiently, and to the overall benefit of the student.

So despite a rather pessimistic view of state funding for higher education, there is hope that greater access to higher education can result. If higher education institutions decide to grasp the potential of online learning and put the work into making it cost-efficient for themselves and beneficial for students, the promise of a steady revenue stream may help motivate and fuel the process. But while revenue provides the fuel, the pump will be provided by the dedication of many individuals who find the benefits of online learning - in terms of greater learning and a lower DFW rate-a reason to put the time and effort into the transformation. While resources are essential, attempting to address the universal right to higher education is an ideal worthy of our best efforts. 


\section{REFERENCES}

1. Hebel, S. and J. Selingo. For public colleges, a decade of generous state budgets is over. The Chronicle of Higher Education 47(32): A10, April 20, 2001.

2. Potter, W. State lawmakers again cut higher-education spending. The Chronicle of Higher Education 49(48): A22, August 8, 2003.

3. Walters, A. K. Long-term forecast for state spending on higher education is gloomy, report says. The Chronicle of Higher Education 52(27): A21, March 10, 2006.

4. Breneman, D. W. For colleges, this is not just another recession. The Chronicle of Higher Education: B7, June 14, 2002. http://chronicle.com/prm/weekly/v48/i40/40b00701.htm.

5. Sepp, P. Rising property taxes fuel taxpayer revolts. http://www.heartland.org/Article.cfm?artId=17540.

6. Meehan, T. A welcome break for homeowners. http://www.terrymeehan.com/pdf/State by State Property Tax Directory.pdf.

7. Fischer, K. State spending on colleges bounce back. The Chronicle of Higher Education 52(19): A1, January 13, 2006.

8. Walters, A. K. States are flush with cash, but colleges face competition for the money. The Chronicle of Higher Education 52(42): A23, June 23, 2006.

9. Rossi, P. H., J. D. Wright \& S. R. Wright. The theory and practice of applied social research. Evaluation Quarterly 2(2): 171-91, 1978.

10. Majchrzak, A. Methods for Policy Research. New York: Sage Publications, 1984.

11. Center for the Study of Education Policy. An Annual Compilation of Data on State Tax Appropriations for the General Operation of Higher Education. Normal, IL: Illinois State University. http://www.grapevine.ilstu.edu/.

12. National Association of State Budget Officers. Fiscal Survey of the States for 2006. Washington, D.C.: National Governors Association and National Association of State Budget Officers, 2006. http://www.nasbo.org/Publications/PDFs/Fall\%202006\%20Fiscal\%20Survey\%20of\%20States.pdf .

13. State Higher Education Executive Officers. State Higher Education Finance FY 2006. Boulder, CO: SHEEO, 2007. http://www.sheeo.org/finance/shef_fy06.pdf.

14. Western Interstate Commission on Higher Education. Knocking at the College Door. http://www.wiche.edu/policy/Knocking/1988-2018/index.asp .

15. National Center for Higher Education Management Systems. The NCHEMS Information Center for State Higher Education Policymaking and Analysis. http://www.higheredinfo.org/.

16. Boyd, D. State spending for higher education in the coming decade. Boulder, CO: National Center for Higher Education Management Systems, 2002. http://www.nchems.org/pubs/docs/State_Spending.pdf.

17. National Center for Education Statistics. Enrollment in educational institutions, by level and control of institution (Table 3). Washington, DC: U.S. Department of Education. http://nces.ed.gov/programs/digest/d05/tables/dt05_003.asp.

18. Allen, I. E., \& J. Seaman. Entering the Mainstream. Needham, MA: The Sloan Consortium, 2004. http://www.sloan-c.org/resources/entering_mainstream.pdf.

19. Allen, I. E., \& J. Seaman. Making the Grade. Needham, MA: The Sloan Consortium, 2006. http://www.sloan-c.org/publications/survey/pdf/making_the_grade.pdf.

20. National Center for Education Statistics. Postsecondary expectations, plans, and attendance through 1994. Washington, DC: NCES, 1998. http://nces.ed.gov/pubs98/access/98105-9.asp.

21. National Center for Public Policy and Higher Education. The affordability of higher education. http://www.highereducation.org/reports/affordability_pa/affordability_pa.shtml.

22. Meyer, K. A. Cost-efficiencies of online learning. ASHE Higher Education Report Series 32(1). San Francisco: Jossey-Bass, 2006.

23. Twigg, C. A. Improving quality and reducing costs: The case for redesign. In Course Corrections 32-49, 2005. http://www.collegecosts.info/pdfs/solution_papers/Collegecosts_Oct2005.pdf. 
24. Twigg, C. A. Improving quality and reducing cost: Designs for effective learning. Change 35(4): 2329, 2003.

25. Twigg, C. A. Improving quality and reducing costs: New models for online learning. Educause Review 38(5): 28-38, 2003. http://www.educause.edu/ir/library/pdf/erm0352.pdf.

26. Twigg, C. A. Improving learning and reducing costs: Lessons learned from round I of the Pew Grant Program in Course Redesign, 2002. http://center.rpi.edu/PCR/R1Lessons.html.

27. Waddoups, G. L., G. L. Hatch \& S. Butterworth. Balancing efficiency and effectiveness in first year reading and writing. In J. Bourne \& J. C. Moore (Eds.), Elements of Quality Online Education: Practice and Direction, vol. 4, 103-115. Needham, MA: The Sloan Consortium, 2003.

28. Campbell, J. O., J. R. Bourne, P. J. Mosterman, M. Nahvi, R. Rassai, A. J. Brodersen \& M. Dawant. Cost-effective distributed learning with electronics labs. Journal of Asynchronous Learning Networks 8(3): 5-10, 2004. http://www.sloan-c.org/publications/jaln/v8n3/pdf/v8n3_campbell.pdf.

29. Fisher, S. \& T. I. Nygren. Experiments in the cost-effective uses of technology in teaching: Lessons from the Mellon program so far, 2000. http://www.ceutt.org.

30. Arvan, L., J. C. Ory, C. D. Bullock, K. K. Burnaska \& M. Hanson. The SCALE efficiency projects. Journal of Asynchronous Learning Networks 2(2): 33-60, 1998.

http://www.sloan-c.org/publications/jaln/v2n2/pdf/v2n2_arvan.pdf.

31. Milam, J. Cost analysis of online courses. Paper presented at the Annual Forum of the Association for Institutional Research. Cincinnati, OH: May 21-23, 2000.

32. Bodain, Y. \& J. Robert. Investigating distance learning on the Internet, 2000. http://www.isoc.org/inet2000/cdproceedings/6a/6a_4.htm.

33. Ehrmann, S. C. Asking the hard questions about technology use and education. Change 31(2): 2529, 1999.

34. Harkness, W. L., J. L. Lane \& J. T. Harwood. A cost-effective model for teaching elementary statistics with improved student performance. Journal of Asynchronous Learning Networks 7(2): 817, 2003. http://www.sloan-c.org/publications/jaln/v7n2/pdf/v7n2_harkness.pdf.

35. Chickering, A. W. \& Z. F. Gamson. Seven principles for good practice in undergraduate education. AAHE Bulletin 39(7): 3-7, 1987. http://www.cord.edu/dept/assessment/sevenprin.htm.

36. Miller, G. E. Penn State's World Campus: A case study in achieving cost efficiencies in ALN. In J. Bourne \& J. C. Moore (Eds.), Online Education, 163-172. Needham, MA: The Sloan Consortium, 2001.

37. Twigg, C. A. Improving learning and reducing costs: Redesigning large enrollment courses. Center for Academic Transformation at Rensselaer Polytechnic Institute: Troy, NY, 1999.

38. Brown, G., C. B. Myers \& S. Roy. Formal course design and the student learning experience. Journal of Asynchronous Learning Networks 7(3): 66-76, 2003. http://www.sloan-c.org/publications/jaln/v7n3/v7n3_myers.asp.

39. Henderson, T. Using activity-based costing to inform university assessment. A paper presented at the Western Cooperative for Educational Telecommunications Annual Conference: November 11, 2004, San Antonio, Texas.

40. Meyer, K. A., J. Bruwelheide \& R. Poulin. Developing knowledge through practical experience: The principles of financial sustainability for online programs. The Online Journal of Distance Learning Administration 10(2): 2007. http://www.westga.edu/ distance/ojdla/summer102/meyer102.htm.

\section{ABOUT THE AUTHOR}

Dr. Meyer is currently associate professor of higher and adult education at The University of Memphis specializing in online learning and higher education. She is the author of Cost-efficiencies of Online Learning, a 2006 publication of the ASHE Higher Education Report Series. For over three years, she was Director of Distance Learning and Technology for the University and Community College System of Nevada. Prior to this, she served over 8 years as Associate Director of Academic Affairs for the Higher 
Education Coordinating Board in the state of Washington and was responsible for technology planning and policy related to online learning. 